\begin{tabular}{c|c|c}
\hline \hline Vol. 264: 123-135, 2003 & MARINE ECOLOGY PROGRESS SERIES \\
Mar Ecol Prog Ser & Published December 15 \\
\hline
\end{tabular}

\title{
Summertime foraging ecology of North Atlantic right whales
}

\author{
Mark F. Baumgartner ${ }^{1,3, *}$, Bruce R. Mate ${ }^{2}$ \\ ${ }^{1}$ College of Oceanic and Atmospheric Sciences, Oregon State University, 104 Ocean Administration Building, Corvallis, \\ Oregon 97331, USA. \\ ${ }^{2}$ Coastal Oregon Marine Experiment Station, Hatfield Marine Science Center, Oregon State University, Newport, \\ Oregon 97365, USA
}

${ }^{3}$ Present address: Biology Department, MS \#33, Woods Hole Oceanographic Institution, Woods Hole, Massachusetts 02543, USA

\begin{abstract}
North Atlantic right whales were instrumented with suction-cup mounted, time-depth recorders (TDR) during the summers of 2000 and 2001 to examine their diving and foraging behavior. Simultaneous observations of temperature, salinity and the vertical distribution of their principal prey, Calanus finmarchicus stage 5 copepodites (C5), were obtained along each whale's track with a conductivity-temperature-depth instrument (CTD) and an optical plankton counter (OPC). Right whale feeding dives were characterized by rapid descent from the surface to a particular depth between 80 and $175 \mathrm{~m}$, remarkable fidelity to that depth for 5 to $14 \mathrm{~min}$ and then rapid ascent back to the surface. The average depth of dive was strongly and positively correlated with both the average depth of peak $C$. finmarchicus $\mathrm{C} 5$ abundance and the average depth of the bottom mixed layer's upper surface. Significantly longer surface intervals were observed for reproductively active females and their calves when compared to other individuals, indicating that this critical segment of the population may be at increased risk of ship strikes owing to their diving behavior. Ingestion rates calculated from TDR and OPC data exceeded estimated daily metabolic requirements for most of the tagged right whales; however, short deployment durations and uncertainty in metabolic rates make it impossible to judge whether individual right whales were obtaining sufficient energy to meet the metabolic costs of reproduction. Improvements in attachment durations and the development of novel methods to estimate the metabolic rates of large whales in situ are required to determine whether right whale reproduction is limited by insufficient food resources.
\end{abstract}

KEY WORDS: Right whale • Eubalaena glacialis · Calanus finmarchicus · Diving behavior • Energetics · Aggregation

Resale or republication not permitted without written consent of the publisher

\section{INTRODUCTION}

The foraging behavior of marine mammals is difficult to observe directly, because it often occurs below the sea surface. The miniaturization of sensors and data loggers in recent decades has facilitated the development of time-depth recorders (TDR) to study the diving behavior of marine mammals (Kooyman 1989, Costa 1993), but obtaining information about prey distribution and abundance at the same temporal and spatial scales of the TDR is rarely feasible. The North Atlantic right whale Eubalaena glacialis occupies a unique trophic position in the marine ecosystem; it is one of the world's largest predators (up to $17 \mathrm{~m}$ ), yet it feeds primarily on one of the smallest marine animals, the 2 to $3 \mathrm{~mm}$ long calanoid copepod Calanus finmarchicus. Assessing the abundance of this copepod at spatial scales that are relevant to a right whale $(10 \mathrm{~s}$ of $\mathrm{cm}$ to $\mathrm{m}$ in the vertical, $10 \mathrm{~s}$ to $100 \mathrm{~s}$ of $\mathrm{m}$ in the horizontal) is nearly impossible with conventional net sampling methods. Targeted net sampling is only feasible when right whales are feeding at or very near the surface 
and copepod patches can be visually identified (Watkins \& Schevill 1976, Wishner et al. 1988, 1995, Mayo \& Marx 1990, Beardsley et al. 1996). With the advent of instrumentation to estimate the abundance of zooplankton, however, the distribution of $C$. finmarchicus can now be adequately and rapidly sampled at spatial scales much closer to those utilized by the whales.

North Atlantic right whales are one of the most endangered large whales, and despite international protection from whaling since the 1930s, this species has failed to recover to its pre-exploitation population levels (Clapham et al. 1999). Recent estimates suggest that only around 300 individuals remain (Knowlton et al. 1994, IWC 2001, Kraus et al. 2001), and the current, unacceptably high mortality rates (due, in part, to ship strikes and fishing gear entanglements) are projected to cause extinction within a few centuries (Caswell et al. 1999, Fujiwara \& Caswell 2001). Consequently, there is an urgent need for information about the habitat and habitat use of right whales to improve conservation efforts. There is also a need to improve our understanding of food availability and foraging success as determinants of reproductive success. One of the hypotheses to explain the lack of recovery in this population states that centuries of depressed abundance due to whaling has allowed other predators of Calanus finmarchicus to flourish (e.g. planktivorous fish, see Payne et al. 1990), so sufficient food resources to support substantial population growth no longer exist (IWC 2001). Recent results linking temporal variability in both crude right whale survival probability (Fujiwara \& Caswell 2001) and right whale reproductive success (Kenney et al. 2001) to the North Atlantic Oscillation, which, in turn, affects C. finmarchicus abundance (Fromentin \& Planque 1996, Greene \& Pershing 2000, Conversi et al. 2001), seem consistent with this hypothesis.

Right whales have been observed feeding on older copepodite stages of Calanus finmarchicus in Cape Cod Bay (Watkins \& Schevill 1976, Mayo \& Marx 1990) and in the Great South Channel (Wishner et al. 1988, 1995, Beardsley et al. 1996) in the late winter and spring. Surface feeding occurs occasionally, but subsurface feeding is much more common (Watkins \& Schevill 1976, Mayo \& Marx 1990, Kenney et al. 1995). During the summer, right whales can be found in the lower Bay of Fundy and on the SW Scotian Shelf, where they continue to feed on older stages of $C$. finmarchicus (Stone et al. 1988, Murison \& Gaskin 1989, Woodley \& Gaskin 1996). At this time of year, the bulk of the C. finmarchicus population consists of stage 5 copepodites (C5) that are in a resting state deep in the water column (Sameoto \& Herman 1990, Miller et al. 1991). Net sampling by Murison \& Gaskin (1989) in the lower Bay of Fundy indicated that C. finmarchicus C5 was the dominant zooplankter near right whales and that these copepods occurred at depths below $100 \mathrm{~m}$. Both Murison \& Gaskin (1989) and Goodyear (1993) observed right whales diving to depths below $100 \mathrm{~m}$ in the lower Bay of Fundy.

We report here on a study of right whale diving and foraging behavior in the lower Bay of Fundy and on the southwestern Scotian Shelf. Right whale diving behavior was monitored via suction-cup mounted TDRs, and observations of Calanus finmarchicus C5 vertical distribution were obtained near the tagged whales with an optical plankton counter (OPC). These measurements were used to investigate the hypothesis that right whales exploit high abundances of $C$. finmarchicus C5 concentrated in discrete layers. Kenney et al. (1986) suggested that foraging must occur on discrete layers of zooplankton for right whales to satisfy their energetic demands. We used the OPC to sample these discrete layers at temporal and spatial scales similar to those of the foraging whales. Simultaneous observations of temperature and salinity obtained with a conductivity-temperature-depth instrument (CTD) also allowed an investigation of the hydrographic features that promote the formation or persistence of these layers. To address the hypothesis of insufficient food resources, right whale ingestion rates were estimated from the TDR and OPC data and compared to daily metabolic requirements.

\section{MATERIALS AND METHODS}

The tag used during the 2000 summer field season consisted of a modified Wildlife Computers model MK7 TDR that recorded pressure (converted to depth at a resolution of $2 \mathrm{~m}$ ), temperature and relative light intensity every second. The tag needed to be recovered for access to these data. The TDR also included a slot in which a Telonics model CHP-1P, $149 \mathrm{MHz}$ radio transmitter was placed. Syntactic foam floatation was molded around one end of the TDR to make the entire tag positively buoyant. The tag was attached to a whale via a silicone suction cup and detachment was uncontrolled. In 2001, a Vemco model V22P acoustic transmitter was included in the tag to allow tracking while a whale was submerged. The acoustic transmitter emitted $36 \mathrm{kHz}$ pulses at $165 \mathrm{~dB}$ (re $1 \mu \mathrm{Pa}$ at $1 \mathrm{~m}$ ) at intervals proportional to the depth of the tag (e.g. every $1.03 \mathrm{~s}$ at $10 \mathrm{~m}$ and $0.76 \mathrm{~s}$ at $200 \mathrm{~m}$ ). A corrosive release mechanism was also incorporated in the tag in 2001 that was designed to provide reliable attachment durations of between 1 and $2 \mathrm{~h}$. The suction cup was changed in 2001 to a more robust, rubber material. In both 2000 and 2001, the tag was attached with a $9 \mathrm{~m}$ 
telescoping pole from an elevated platform in the bow of a $7.5 \mathrm{~m}$ rigid-hulled inflatable boat (RHIB).

Visual observations were used to assess the reaction of whales to close boat approaches. However, the value of these observations in gauging the overall effects of tagging is unclear. It is important to consider the effect of tagging on biologically meaningful activities (e.g. feeding, breeding) and to use objective data when doing so. Toward that end, the diving behavior of the tagged whales was also investigated for reactions to close boat approach and tagging. The tagged right whales engaged primarily in feeding behavior (see 'Results'), so only whales tagged for over $1 \mathrm{~h}$ with 2 or more feeding dives were examined. The characteristics of the first feeding dive (duration, average dive depth, descent speed, ascent speed) were compared to those of the second, third, fourth and last observed feeding dives to document any significant changes in diving behavior as a result of the tag attachment process. This first feeding dive occurred up to 7.5 min after tag deployment. In addition, the characteristics of the second feeding dive were compared to those of the third, fourth and last dives, and the characteristics of the third feeding dive were compared to those of the fourth and last dives.

Following deployment, the whale was tracked at the surface via the radio transmitter, and in 2001, via the acoustic transmitter when the whale was submerged. Recovery of the tag after detachment was facilitated with these same systems. Right whales were tagged and tracked only during daylight hours. Radio tracking was accomplished with a 4-element Yagi antenna and a receiver. Bearing alone was estimated from the received signal intensity, and the range of the system was over $1 \mathrm{~km}$. Acoustic tracking was accomplished with a directional hydrophone and a receiver. Bearing and horizontal distance to the animal were estimated from the received acoustic signal intensity and, with some experience, these could be judged to within $15^{\circ}$ and 50 to $100 \mathrm{~m}$, respectively. The pulse interval was measured, converted to depth and displayed by the acoustic receiver, so an estimate of the depth of the whale was also available in real time. To test the range of the acoustic system, a transmitter was suspended in the lower Bay of Fundy at $75 \mathrm{~m}$ and detectability was tested at various distances. The maximum distance tested was $1 \mathrm{~km}$ before weather forced an end to the experiment, but the signal was easily detected at this maximum distance.
Upon each resurfacing of a tagged whale after a long dive, the resurfacing position was obtained by parking a RHIB on the exact location and obtaining a global positioning system (GPS) measurement. Shortly thereafter, NOAA Ship 'Delaware II' would occupy this same position and deploy an instrument package consisting of a Seabird model SBE19 CTD and a Focal Technologies model OPC-1T. These instruments were housed in a rosette cage and deployed in a vertical cast at a nominal $0.5 \mathrm{~m} \mathrm{~s}^{-1}$ (2000) or $1.0 \mathrm{~m} \mathrm{~s}^{-1}$ (2001) descent rate. The CTD provided the vertical distribution of temperature and salinity and the OPC provided the vertical distribution of particle abundance in sizes ranging from 0.25 to $20 \mathrm{~mm}$ (Herman 1988, 1992). The abundance of Calanus finmarchicus $\mathrm{C} 5$ was estimated from the OPC data using a calibration equation developed from comparisons between OPC measurements and net samples collected in this same region (Baumgartner 2003). During tracking, behavioral observations and social interactions were noted and when possible photographs were taken for comparison with the New England right whale catalog (Hamilton \& Martin 1999) to identify tagged individuals.

Dives were defined as any vertical excursion below $50 \mathrm{~m}$. The period between these dives was typically spent at or just below the surface. Vertical excursions between the surface and $50 \mathrm{~m}$ typically occurred during traveling or associations with other right wales. Dives were considered to be initiated when the vertical descent speed exceeded $0.5 \mathrm{~m} \mathrm{~s}^{-1}$ and the descent portion of the dive was terminated when the vertical descent speed dropped below $0.5 \mathrm{~m} \mathrm{~s}^{-1}$ (Fig. 1).

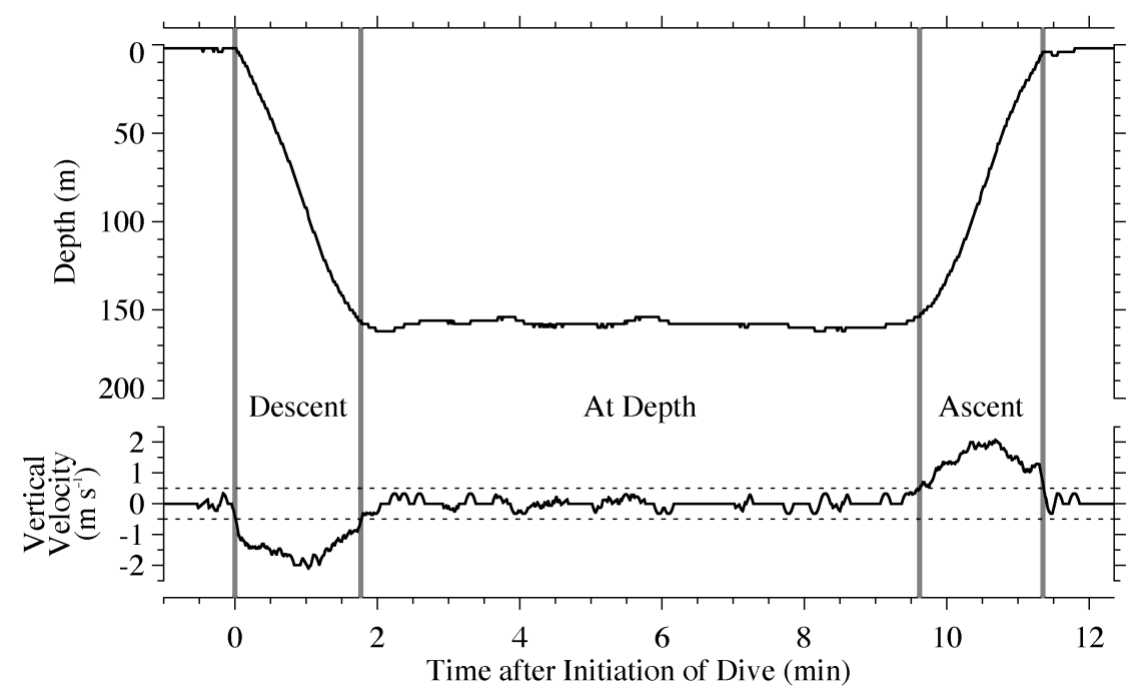

Fig. 1. Eubalaena glacialis. Typical right whale feeding dive with descent, at depth and ascent portions shown. By convention, the descent portion begins when the downward velocity exceeds $0.5 \mathrm{~m} \mathrm{~s}^{-1}$ and ends when the downward velocity drops below $0.5 \mathrm{~m} \mathrm{~s}^{-1}$. Likewise, the ascent portion begins when the upward velocity exceeds $0.5 \mathrm{~m} \mathrm{~s}^{-1}$ and ends when the upward velocity drops below $0.5 \mathrm{~m} \mathrm{~s}^{-1}$ 
Ascent was initiated when the vertical ascent speed exceeded $0.5 \mathrm{~m} \mathrm{~s}^{-1}$ and the dive was terminated when the vertical ascent speed dropped below $0.5 \mathrm{~m}$ $\mathrm{s}^{-1}$. The dive duration was defined as the time between the initiation of the descent and the termination of the ascent. The duration at depth was defined as the time between the termination of the descent and the initiation of the ascent. The mean and SD of the dive depth were computed during the at-depth portion of the dive (i.e. between the termination of the descent and the initiation of the ascent). Classification of dives was facilitated by a Ward's minimum-variance cluster analysis and visualization with multivariate star plots (Johnson 1998). The cluster analysis and visualization were conducted on the dive duration, duration at depth, descent speed, ascent speed and SD of the dive depth. Dives were classified into 3 types: feeding, V-shaped and 'other'. Surface intervals were measured after feeding dives only when the successive dive was also a feeding dive and no social activity was observed. Surface intervals were also expressed as a percentage of the total dive cycle time (PCST: after Dolphin 1987). The total dive cycle time was computed as the sum of the dive duration and the succeeding surface interval.

The vertical distribution of Calanus finmarchicus C5 was estimated from the calibrated OPC data in $4 \mathrm{~m}$ depth strata below $50 \mathrm{~m}$. The depth of the peak $C$. finmarchicus $\mathrm{C} 5$ abundance was chosen as the midpoint of the depth stratum containing the maximum $C$. finmarchicus C5 concentration. The lower Bay of Fundy is characterized by strong tidal flow that interacts with the sea floor to create a turbulent, well-mixed bottom layer. To examine the potential relationships among this bottom mixed layer, the vertical distribution of $C$. finmarchicus $\mathrm{C} 5$ and the diving behavior of the tagged right whales, the depth of the top of this layer was determined from the CTD data. The top of this boundary layer was defined as the deepest depth at which the density differed from the bottom density by at least $0.05 \mathrm{~kg} \mathrm{~m}^{-3}$.

Each tagged whale was considered an independent observation. Therefore, individual dive characteristics (e.g. mean dive depth, dive duration, duration at depth) and associated environmental conditions (peak Calanus finmarchicus C5 abundance, depth of peak abundance and bottom mixed layer depth) were averaged to provide a single observation of each variable for each whale. For comparisons between dive characteristics and environmental conditions, only data for dives with accompanying CTD/OPC casts were averaged. Dive characteristics and associated environmental conditions were compared using correlation analysis.
Total ingestion of Calanus finmarchicus C5 $\left(I_{\mathrm{d}}\right)$ was estimated for each feeding dive as

$$
I_{\mathrm{d}}=A_{\mathrm{g}} S T_{\mathrm{d}} E_{\mathrm{C} 5} C
$$

where $A_{\mathrm{g}}$ is the area of the whale's gape (the opening through which water enters the mouth), $S$ is the swimming speed, $T_{\mathrm{d}}$ is the duration at depth, $E_{\mathrm{C} 5}$ is the energy (calorific) content of a single $C$. finmarchicus C5 and $\mathrm{C}$ is the estimated C. finmarchicus C5 concentration available to the whale. The total ingestion rate $\left(I^{\prime}\right)$ during the period when the whale was tagged was estimated as follows:

$$
I^{\prime}=\frac{T_{\mathrm{f}} \sum I_{\mathrm{d}}}{T_{\mathrm{t}} \sum T_{\mathrm{d}}}
$$

where $T_{\mathrm{f}}$ is the total time spent at depth during feeding dives, $T_{\mathrm{t}}$ is the total time the tag was attached to the whale and the summation of $I_{\mathrm{d}}$ and $T_{\mathrm{d}}$ occurred over all dives that had accompanying CTD/OPC casts. The ratio of $T_{\mathrm{f}}$ to $T_{\mathrm{t}}$ is considered the fraction of time spent feeding. The gape area was assumed to be $1.21 \mathrm{~m}^{2}$ (Mayo et al. 2001) and the energy content of a single C. finmarchicus C5 was fixed at $1.62 \times 10^{-3} \mathrm{kcal}$ cope$\operatorname{pod}^{-1}$ (Comita 1966) or $6.78 \mathrm{~J} \mathrm{copepod}^{-1}(1 \mathrm{kcal}=$ $4186.8 \mathrm{~J})$. In 2001, improved tracking with the acoustic transmitter allowed accurate measurements of both diving and resurfacing locations. The distance between the diving and resurfacing locations divided by the dive duration was used as an estimate of the swimming speed during feeding ( $S$ in Eq. 1). These speeds must be considered minimum speeds, however, since we do not know whether the whales foraged along straight-line paths between the diving and resurfacing positions. To account for this, swimming speeds were increased to $1.5 \mathrm{~m} \mathrm{~s}^{-1}$ whenever the observed minimum speed was less than $1.5 \mathrm{~m} \mathrm{~s}^{-1}$. Speeds were assumed to be $1.5 \mathrm{~m} \mathrm{~s}^{-1}$ for all dives in 2000. In Cape Cod Bay, Mayo et al. (2001) observed average swimming speeds during surface feeding of $1.34 \mathrm{~m} \mathrm{~s}^{-1}$ and Watkins \& Shevill (1976) report speeds of 'up to 3 knots' or $1.54 \mathrm{~m} \mathrm{~s}^{-1}$. Minimum swimming speeds in the present study averaged nearly $1 \mathrm{~m} \mathrm{~s}^{-1}$ (see Table 3 in 'Results'); however, subsurface foraging paths in the Bay of Fundy are not necessarily straight (D. P. Nowacek pers. comm.). Therefore, $1.5 \mathrm{~m} \mathrm{~s}^{-1}$ is assumed to be a reasonable estimate of true speed during feeding.

To investigate whether sufficient food was available to the tagged whales, the rate of ingestion was compared to the estimated rate needed to meet the daily metabolic requirements for maintenance in right whales. For simplicity, a right whale's day was divided into 2 activities: foraging and resting. The metabolic rate during foraging was assumed to be equal to the diving metabolic rate (DMR). Assuming that the 
tagged right whales were able to continue to feed at $I^{\prime}$ for $T \mathrm{~h}$ each day, the fraction of the daily metabolic requirement met by each whale is

$$
\frac{\text { daily assimilation }}{\text { daily requirement }}=\frac{A I^{\prime} T}{\operatorname{DMR}(T)+\operatorname{RMR}(24-T)}
$$

where $A$ is the assimilation efficiency and RMR is the resting metabolic rate. The time required to meet the daily metabolic requirement $\left(T_{\text {req }}\right)$ is then

$$
T_{\text {req }}=\frac{24 \mathrm{RMR}}{A I^{\prime}+\mathrm{RMR}-\mathrm{DMR}}
$$

Both DMR and RMR were assumed to be multiples of the basal metabolic rate (BMR), which was estimated as

$$
\mathrm{BMR}=\frac{4186.8}{86400}\left[70 M^{0.75}\right]
$$

where $M$ is the mass of a right whale in $\mathrm{kg}$. The term in brackets is after Kleiber (1975) and the first term converts Kleiber's expression from $\mathrm{kcal} \mathrm{d}^{-1}$ to $\mathrm{W}$ (or $\mathrm{J} \mathrm{s}^{-1}$ ). The assimilation efficiency and body mass are assumed to be 0.80 (Lockyer 1981) and $40000 \mathrm{~kg}$ (Kenney \& Winn 1986), respectively; therefore, $\mathrm{BMR}=0.96 \times 10^{4}$ $\mathrm{W}$. The magnitude of DMR is unknown for right whales, but for other species, DMR is $1.5-2 \times$ BMR in Weddell seals (Kooyman et al. 1973, Castellini et al. 1992), $2-3 \times$ BMR in northern elephant seals (Costa \& Williams 1999) and nearly $6 \times$ BMR in the bottlenose dolphin and otariids (sea lions and fur seals) (Costa \& Gentry 1986, Costa et al. 1989, Costa \& Williams 1999). When compared to other marine mammals, the DMR for right whales is probably low since the energetic costs associated with continuous filter feeding do not appear particularly expensive (relative to lunge feeding in rorquals, for instance; Croll et al. 2001) and their insulating blubber layer is thick. Recent energetic investigations of bowhead whales, a closely related species to the right whale, suggest these whales have very low metabolic rates due, in part, to a very thick blubber layer and a low core temperature (J. C. George pers. comm.). We assume here that $\mathrm{DMR}=2 \times \mathrm{BMR}$ and $\mathrm{RMR}$ $=1 \times \mathrm{BMR}$. For consistency with the literature, we also present ingestion rate as a fraction of the ingestion rate required to meet basal metabolic requirements. This latter rate $\left(I^{\prime}{ }_{\mathrm{BMR}}\right)$ is estimated as

$$
I_{\mathrm{BMR}}^{\prime}=\frac{1}{A} \mathrm{BMR}
$$

or $1.20 \times 10^{4} \mathrm{~W}$.

\section{RESULTS}

A total of 28 right whales were tagged in the lower Bay of Fundy between 11 July and 28 August 2000 (Fig. 2). All but 2 of the tags were recovered. The

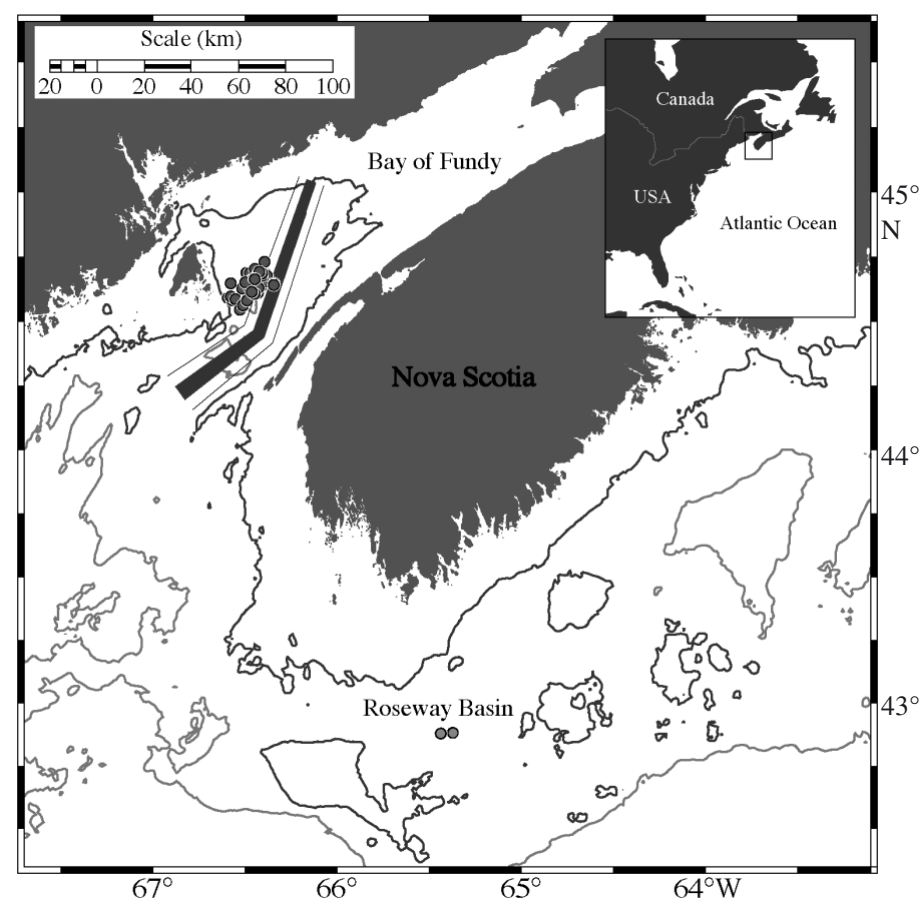

Fig. 2. Map of study area. (O) Tagging locations in the lower Bay of Fundy and Roseway Basin. Shipping lanes through the lower Bay of Fundy at the time of this study and the $91 \mathrm{~m}$ (50 fathom) and $200 \mathrm{~m}$ isobaths are also shown

median duration of attachment was 28 min and $23.1 \%$ $(\mathrm{n}=6)$ of the tagging events exceeded $1 \mathrm{~h}$. During a single event in 2000, a rubber suction cup was used instead of the silicone cup and the resulting attachment duration was $7 \mathrm{~h}$. A total of 63 complete dives was recorded of which $93.7 \%(n=59)$ were feeding dives, $4.8 \%(\mathrm{n}=3)$ were $\mathrm{V}$-shaped and $1.6 \%(\mathrm{n}=1)$ were classified as 'other.' From 11 to 29 August 2001, 25 right whales were tagged and all of the tags were recovered. Of these 25 whales, 6 adults (presumably female) with calves, 2 calves and 1 pregnant (R. M. Rolland pers. comm.) female were tagged. Two of the whales were tagged in Roseway Basin on the southwestern Scotian Shelf and the remaining 23 were tagged in the lower Bay of Fundy (Fig. 2). The median duration of attachment was 86 min and $64.0 \%(n=16)$ of the tagging events exceeded $1 \mathrm{~h}$. A total of $86 \mathrm{com}-$ plete dives was recorded of which $88.4 \%(n=76)$ were feeding dives, $5.8 \%(n=5)$ were $V$-shaped and $5.8 \%$ ( $\mathrm{n}=5$ ) were classified as 'other.' Of the 149 total dives recorded in both 2000 and 2001, 86.6\% (n = 129) had an accompanying CTD/OPC cast which, on average, was conducted $21.5 \mathrm{~min}$ after and $158 \mathrm{~m}$ away from the whale's resurfacing location.

Strong reaction to tagging or the close approach of the RHIB was uncommon. In 2000, $71 \%$ of the 42 whales that were closely approached by the RHIB 
(within $10 \mathrm{~m}$ ) showed no observable reaction (22 of 28 successfully tagged individuals and 8 of 14 unsuccessfully tagged individuals). Of the remaining whales, reactions included lifting the head or flukes, arching the back, rolling to one side, rolling to one side and beating the flukes (on 1 occasion), or performing a head lunge (on 1 occasion). Observations during close boat approaches in 2001 were qualitatively similar to those collected in 2000. The characteristics of the first, second, third, fourth and last feeding dives were compared for the 18 whales that were tagged for over $1 \mathrm{~h}$ and had 2 or more feeding dives. The duration of the first feeding dive was, on average, $13 \%$ ( $\mathrm{n}=18, \mathrm{p}=$ $0.0061), 15 \%(\mathrm{n}=17, \mathrm{p}=0.0039), 17 \%(\mathrm{n}=16, \mathrm{p}=$ $0.0010)$ and $14 \%(\mathrm{n}=12, \mathrm{p}=0.045)$ shorter than the second, third, fourth and last dives, respectively. In contrast, no significant differences in dive duration ( $p>0.05$ ) were detected in comparisons of the second and successive dives or the third and successive dives. Differences in dive duration between the first and successive dives did not depend on the time between tag attachment and the first feeding dive (correlation analysis, $\mathrm{p}>0.5$ ). No significant differences in descent speed, ascent speed or dive depth $(p>0.05)$ were detected in comparisons between the first dive and successive dives.

Based on these results, the effect of the tag attachment process on diving behavior is considered to be small and short-lived; hence, none of the subsequent analyses take this effect into account. Only the duration of the first feeding dive was affected by the tagging process, and the difference between this first dive and successive dives was small ( $15 \%$ shorter). Reduction in dive duration during the first dive is likely caused by inadequate ventilation during the surfacing interval in which the tag was deployed which, in turn, may be due to evasion of the boat by premature diving, longer submergence times between breaths or increased swim speeds.

Feeding dives were characterized by a rapid descent from the surface to a particular depth, remarkable fidelity to that depth for an average of just over $9 \mathrm{~min}$ and then a rapid ascent back to the surface (Fig. 1, Table 1). Ascent speed averaged $0.07 \mathrm{~m} \mathrm{~s}^{-1}(95 \% \mathrm{CI}$ : $0.01-0.13 \mathrm{~m} \mathrm{~s}^{-1}$ ) faster than the corresponding descent speed during feeding dives (one-sample $t$-test, $\mathrm{p}=0.026$ ). Excluding the tagged calves, females with calves and the pregnant female, there was no evidence to suggest that PCST was correlated with either depth ( $\mathrm{r}=0.119, \mathrm{p}=0.73$ ) or dive duration $(\mathrm{r}=0.029, \mathrm{p}=0.93)$. For these indi- viduals, PCST averaged 21.2\% $(\mathrm{n}=11, \mathrm{SD}=4.1 \%$, range $=15.8-30.1 \%$ ) whereas for the tagged calves and females with calves, PCST averaged 34.2\% ( $\mathrm{n}=4$, $\mathrm{SD}=9.2 \%$, range $=24.3-44.3 \%$ ). The PCST for the pregnant female (shown in Fig. 4c) was 51.1\%, which was the highest observed. Excluding the pregnant female, dive durations for calves and females with calves were similar to the other whales (2-sample $t$-test, $\mathrm{p}=0.78$ : however, note low sample size and thus low power of test), but surface intervals were significantly higher (2-sample $t$-test, $\mathrm{p}=0.0011)$. Surface intervals for calves and females with calves averaged $5.69 \min (\mathrm{n}=4, \mathrm{SD}=1.22 \mathrm{~min}$, range $=$ $4.54-6.97 \mathrm{~min}$ ) whereas surface intervals for all other individuals excluding the pregnant female averaged $3.13 \min (\mathrm{n}=11, \mathrm{SD}=0.99 \mathrm{~min}$, range $=1.65-$ $5.06 \mathrm{~min})$. The pregnant female had the highest average surface interval of $11.08 \mathrm{~min}$.

Traveling (e.g. Fig. 3b) and social activity (e.g. Fig. 3c) were also observed and it was during these times that dives classified as V-shaped and 'other' often occurred. Of the 8 dives classified as V-shaped, 5 were to within $10 \mathrm{~m}$ of the bottom mixed layer (e.g. Fig. 4c,d). Of the 6 dives classified as 'other', 2 of the dives were to within $10 \mathrm{~m}$ of the bottom mixed layer (Fig. 3b,c) and 4 were to the sea floor (e.g. Fig. 3b). In all, 5 brief excursions to the bottom were observed (e.g. Fig. 3b,d), but none of these individuals remained at or near the bottom. Feeding dives did not occur near the bottom.

We observed increases in dive duration, descent speed and ascent speed with dive depth during feeding dives which contributed to a positive correlation between duration at depth and dive depth (Table 2). These dive characteristics were also strongly and positively correlated with the depth of the peak Calanus finmarchicus C5 abundance. There was suggestive, but inconclusive evidence that both dive duration and

Table 1. Eubalaena glacialis and Calanus finmarchicus. Summary of feeding dive characteristics for whales that engaged in at least 1 feeding dive while tagged. Dive characteristics were initially averaged to provide a single observation for each whale. Distance and minimum speed were computed from the consecutive diving and resurfacing positions obtained in 2001 only. Prey abundance refers to the peak abundance of $C$. finmarchicus $\mathrm{C} 5$ in the water column

\begin{tabular}{|lcccccc|}
\hline Dive characteristics & $\mathrm{n}$ & Median & Mean & $\mathrm{SD}$ & $95 \% \mathrm{CI}$ & Range \\
\hline Dive duration (min) & 34 & 12.65 & 12.17 & 2.22 & $11.39-12.94$ & $7.83-16.32$ \\
Duration at depth (min) & 34 & 9.50 & 9.39 & 2.29 & $8.59-10.18$ & $4.72-13.55$ \\
Descent speed $\left(\mathrm{m} \mathrm{s}^{-1}\right)$ & 34 & 1.38 & 1.40 & 0.30 & $1.29-1.50$ & $0.81-2.00$ \\
Ascent speed $\left(\mathrm{m} \mathrm{s}^{-1}\right)$ & 34 & 1.54 & 1.47 & 0.26 & $1.38-1.56$ & $0.93-2.05$ \\
Dive depth $(\mathrm{m})$ & 34 & 119.9 & 121.2 & 24.2 & $112.8-129.7$ & $78.7-174.0$ \\
Distance $\left(\mathrm{km}^{2}\right)$ & 18 & 0.59 & 0.59 & 0.20 & $0.49-0.70$ & $0.21-0.94$ \\
Minimum speed $\left(\mathrm{km} \mathrm{h}^{-1}\right)$ & 18 & 0.85 & 0.93 & 0.44 & $0.71-1.15$ & $0.38-1.94$ \\
Prey abundance & 31 & 6219 & 7481 & 4581 & $5800-9161$ & $2059-20610$ \\
$\quad\left(\right.$ copepods $\left.\mathrm{m}^{-3}\right)$ & & & & & & \\
\hline
\end{tabular}



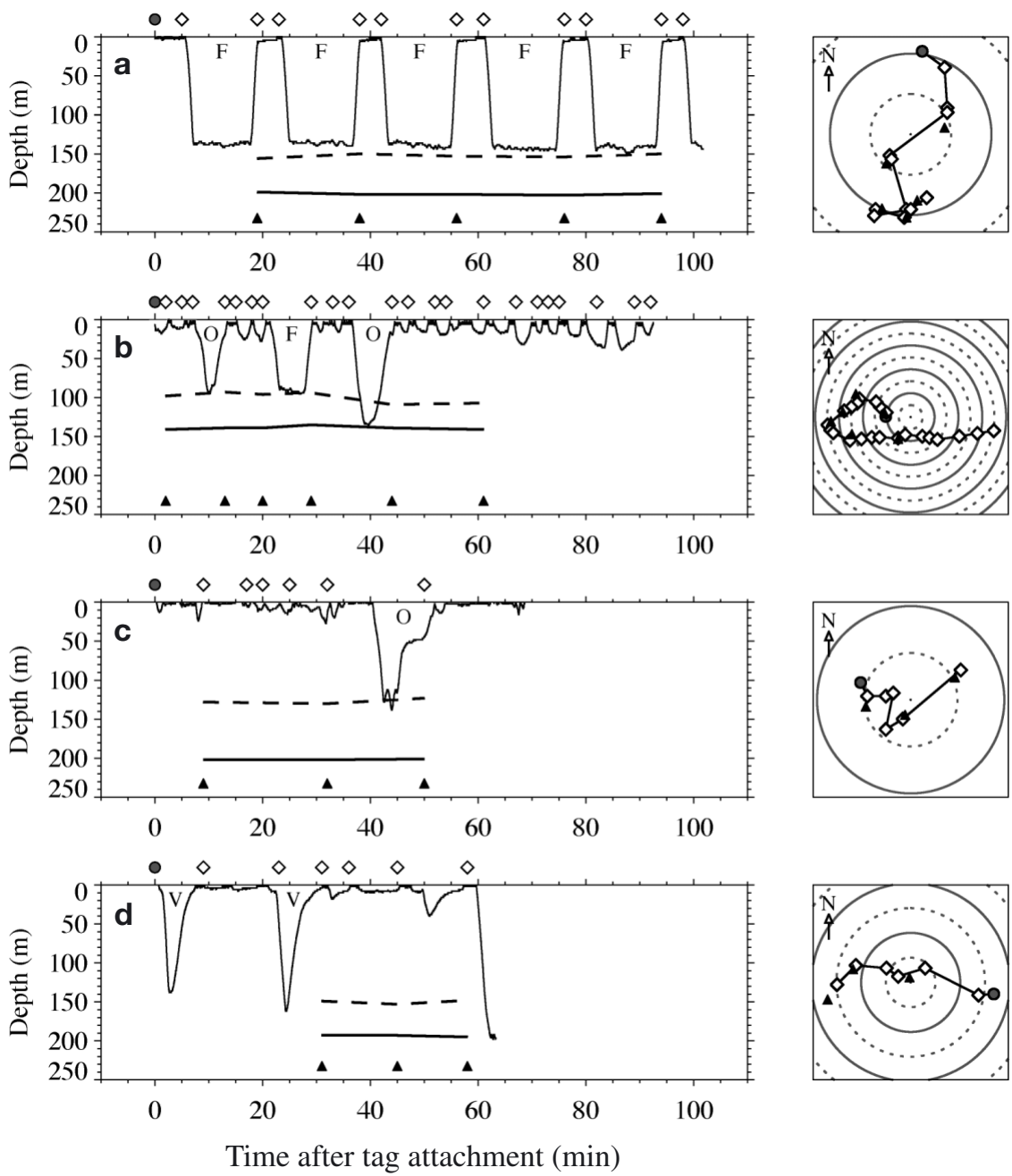

Fig. 3. Eubalaena glacialis. Diving and tracking observations illustrating (a) feeding, (b) traveling, (c) socializing and (d) presumed searching behaviors. Individual dives were classified and labeled as feeding $(F), V$-shaped $(V)$ or 'other' $(\mathrm{O})$. ( $\mathrm{\diamond})$ Times (on the time series) and locations (on the accompanying map) of visual contacts. ( $\mathbf{\Lambda})$ Times and locations at which a resurfacing occurred and a conductivity-temperaturedepth/optical plankton counter (CTD/OPC) cast was conducted. Solid and dashed lines indicate the sea floor and the top of the bottom mixed layer, respectively, measured at the location of each CTD/OPC cast. Concentric lines on the accompanying maps are separated by $0.5 \mathrm{~km}$. Tags detached at depth in (a) and at the bottom in (d) duration at depth were correlated with peak C. finmarchicus C5 abundance ( $\mathrm{r}=0.339, \mathrm{p}=0.062$ for dive duration; $\mathrm{r}=0.353, \mathrm{p}=0.051$ for duration at depth; Table 2). C. finmarchicus C5 were very often aggregated in discrete layers near foraging right whales and the at-depth portion of the whales' dives were spent in or near these layers (Fig. 4). The average depth of dive was strongly correlated with the average depth of peak $C$. finmarchicus C5 abundance $(\mathrm{r}=0.902, \mathrm{p}<0.0001$, Table 2, Fig. 5a). There was no evidence to suggest that the relationship between the average depth of dive and the average depth of maximum $C$. finmarchicus C5 abundance was different from one-to-one $\left(H_{\mathrm{o}}\right.$ : intercept $=0, \mathrm{p}=$ $0.93 ; H_{0}$ : slope $\left.=1, \mathrm{p}=0.76\right)$. The discrete layers of $C$. finmarchicus C5 upon which the whales presumably fed were often observed near the bottom mixed layer (Fig. 4). Consequently, the whales' average dive depth was strongly correlated with the average depth of the bottom mixed layer ( $\mathrm{r}=$ 0.865, p < 0.0001, Fig. 5b). Average dive depths were shallower than the bottom mixed layer by an average of $7 \mathrm{~m}$, however, which indicates that $C$. finmarchicus C5 typically aggregated just above the bottom mixed layer.

Since right whales were observed foraging at the depth of maximum Calanus finmarchicus C5 abundance, total ingestion ( $I_{\mathrm{d}}$ from Eq. 1) was computed for every feeding dive using the estimate of the peak $C$. finmarchicus C5 abundance from the accompanying OPC cast. Ingestion rates ( $I^{\prime}$ from Eq. 2$)$

Table 2. Eubalaena glacialis and Calanus finmarchicus. Correlation matrix of feeding dive characteristics for tagged individuals that engaged in at least 1 feeding dive for which an accompanying CTD/OPC cast was conducted. $\mathrm{n}=31$ for each correlation coefficient. Prey abundance refers to the peak abundance of $C$. finmarchicus $C 5$ in the water column

\begin{tabular}{|c|c|c|c|c|c|c|}
\hline & $\begin{array}{l}\text { Dive } \\
\text { duration }\end{array}$ & $\begin{array}{l}\text { Duration } \\
\text { at depth }\end{array}$ & $\begin{array}{l}\text { Descent } \\
\text { speed }\end{array}$ & $\begin{array}{l}\text { Ascent } \\
\text { speed }\end{array}$ & $\begin{array}{c}\text { Prey } \\
\text { abundance }\end{array}$ & $\begin{array}{l}\text { Depth of peak } \\
\text { prey abundance }\end{array}$ \\
\hline Dive depth & \multirow[t]{6}{*}{$0.586^{* * *}$} & $0.447^{*}$ & $0.470^{* *}$ & $0.533^{* *}$ & 0.093 & $0.902^{* * *}$ \\
\hline Dive duration & & \multirow[t]{5}{*}{$0.974^{* * *}$} & $0.558^{* *}$ & $0.728^{* * *}$ & $0.339^{\mp}$ & $0.569^{* * *}$ \\
\hline Duration at depth & & & $0.635^{* * *}$ & $0.778^{* * *}$ & $0.353^{\mp}$ & $0.469^{* *}$ \\
\hline Descent speed & & & & $0.766^{* * *}$ & 0.234 & $0.538^{* *}$ \\
\hline Ascent speed & & & & & 0.234 & $0.604^{* * *}$ \\
\hline Prey abundance & & & & & & 0.031 \\
\hline${ }^{* * *} \mathrm{p}<0.001,{ }^{* *} 0.0$ & $\leq \mathrm{p}<0.01$ & $\leq \mathrm{p}<0.05$ & $<0.10$ & & & \\
\hline
\end{tabular}



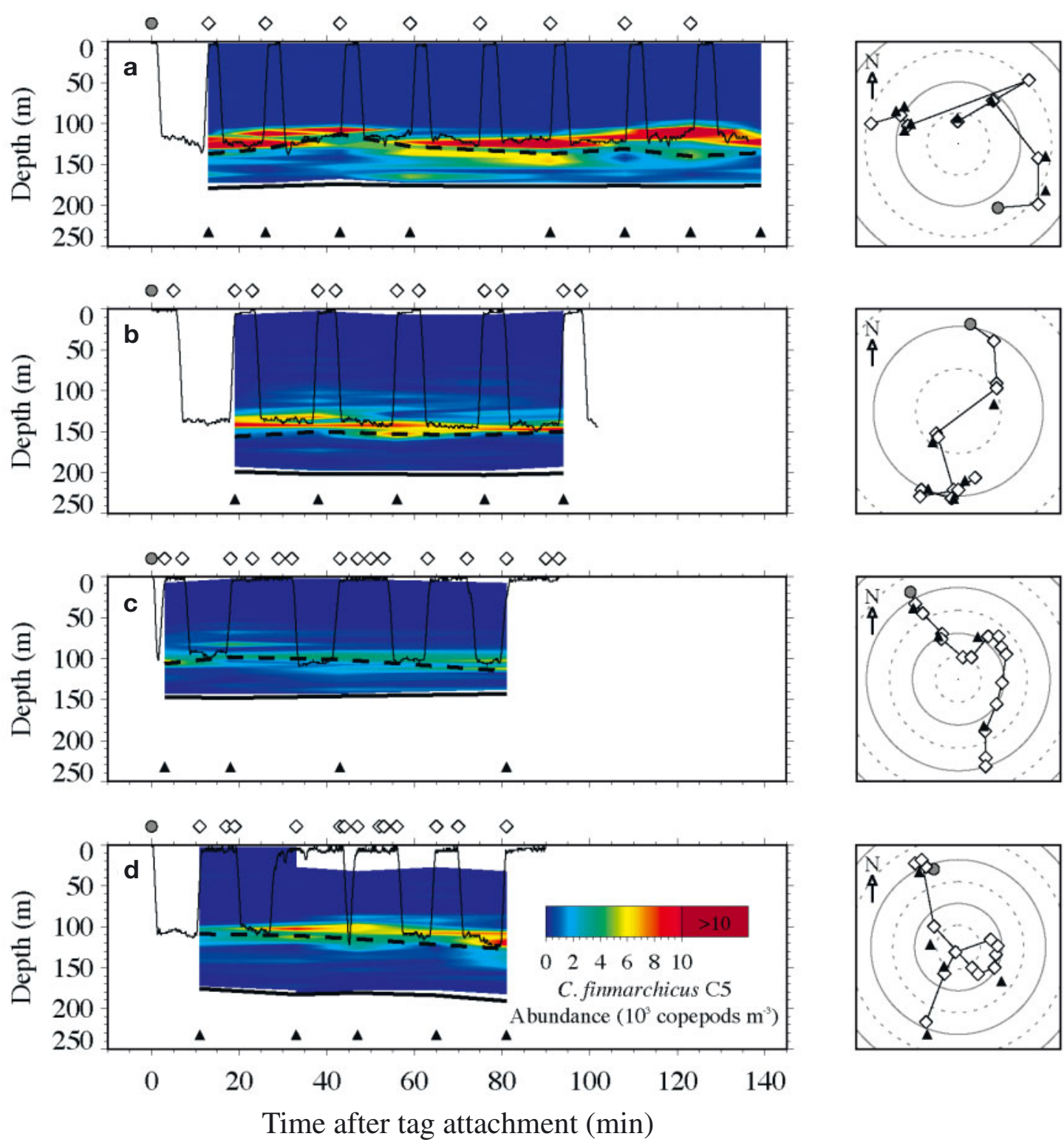

Fig. 4. Eubalaena glacialis and Calanus finmarchicus. (a-d) Examples of diving and tracking observations during feeding behavior. Contoured C. finmarchicus C5 abundance estimated from the OPC casts is shown. Color scale shown in (d) applies to all plots. Symbols and lines are the same as in Fig. 3
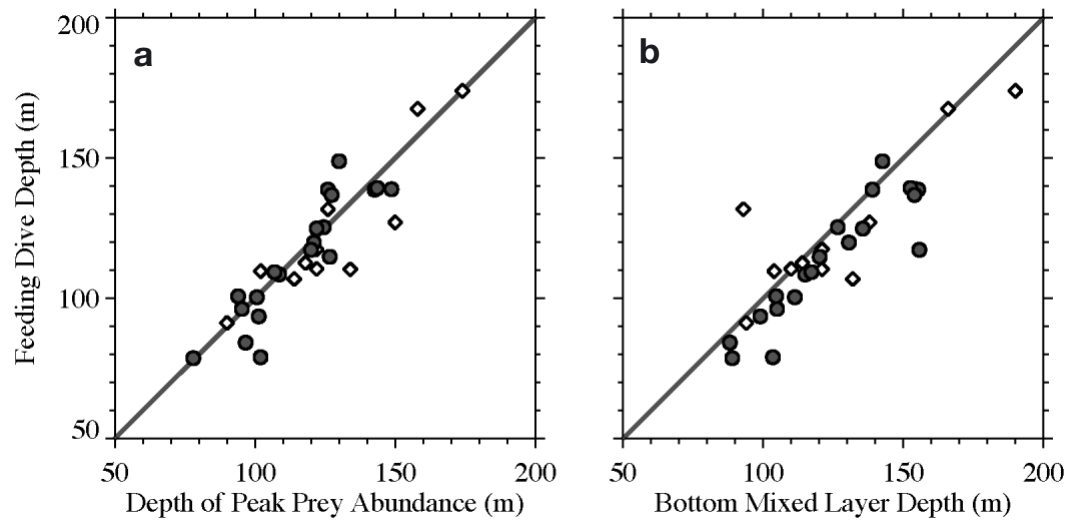

Fig. 5. Eubalaena glacialis and Calanus finmarchicus. Average depth of feeding dive versus (a) average depth of peak $C$. finmarchicus $\mathrm{C} 5$ abundance and (b) average depth of the bottom mixed layer. (0) Tagged whales that had 2 or more feeding dives with accompanying CTD/OPC

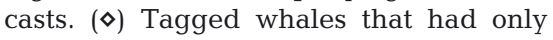
1 feeding dive with an accompanying CTD/OPC cast 
Table 3. Eubalaena glacialis and Calanus finmarchicus. Number of feeding dives, duration of tag attachment, percent time feeding, average minimum speed between diving and resurfacing positions, average peak C. finmarchicus $\mathrm{C} 5$ abundance below $50 \mathrm{~m}$, ingestion rate $\left(I^{\prime}\right)$, ingestion rate as a fraction of the ingestion rate required to meet estimated basal metabolic requirements $\left(I_{\mathrm{BMR}}^{\prime}\right)$, and time required to meet daily metabolic requirement $\left(T_{\text {req }}\right)$ from Eq. (4). Data are from deployments lasting over $1 \mathrm{~h}$. The first column contains the label used for each whale in Fig. 6. Fig. numbers are also provided for those deployments shown in Figs. 3 and 4. Minimum speeds were not calculated for individuals tagged in 2000 (see 'Materials and methods' for explanation). Missing values for $T_{\text {req }}$ indicate $T_{\text {req }}>24 \mathrm{~h}$

\begin{tabular}{|c|c|c|c|c|c|c|c|c|c|}
\hline $\begin{array}{l}\text { Label in } \\
\text { Fig. } 6\end{array}$ & $\begin{array}{l}\text { No. feeding } \\
\text { dives }\end{array}$ & $\begin{array}{c}\text { Attachment } \\
\text { duration (min) }\end{array}$ & $\begin{array}{l}\% \text { time } \\
\text { feeding }\end{array}$ & $\begin{array}{l}\text { Speed } \\
\left(\mathrm{m} \mathrm{s}^{-1}\right)\end{array}$ & $\begin{array}{l}\text { Prey abundance } \\
\text { (copepods } \mathrm{m}^{-3} \text { ) }\end{array}$ & $\begin{array}{c}I^{\prime} \\
\left(10^{4} \mathrm{~W}\right)\end{array}$ & $\begin{array}{c}I^{\prime} \\
\left(\times I_{\mathrm{BMR}}^{\prime}\right)\end{array}$ & $\begin{array}{l}T_{\text {req }} \\
(\mathrm{h})\end{array}$ & Fig. \\
\hline $1^{\mathrm{a}}$ & 0 & 69 & 0.0 & - & - & 0.00 & 0.00 & - & $3 \mathrm{c}$ \\
\hline $2^{\mathrm{a}}$ & 0 & 63 & 0.0 & - & - & 0.00 & 0.00 & - & $3 d$ \\
\hline 3 & 0 & 92 & 0.0 & - & - & 0.00 & 0.00 & - & \\
\hline $4^{\mathrm{b}}$ & 1 & 93 & 5.1 & 1.94 & 5592 & 0.45 & 0.38 & - & $3 b$ \\
\hline 5 & 2 & 102 & 13.5 & 0.38 & 3500 & 0.53 & 0.44 & - & \\
\hline 6 & 6 & 98 & 48.7 & 0.75 & 3124 & 1.89 & 1.57 & - & \\
\hline $7^{b, c}$ & 4 & 93 & 30.7 & 1.01 & 5124 & 1.89 & 1.57 & - & $4 \mathrm{c}$ \\
\hline 8 & 6 & 101 & 63.3 & 0.95 & 3020 & 2.37 & 1.98 & - & \\
\hline 9 & 4 & 66 & 54.5 & 0.52 & 3677 & 2.48 & 2.07 & 22.5 & \\
\hline 10 & 7 & 96 & 45.9 & 1.87 & 3087 & 2.49 & 2.08 & 22.3 & \\
\hline $11^{\mathrm{a}}$ & 9 & 198 & 40.6 & - & 6331 & 3.23 & 2.69 & 14.2 & \\
\hline 12 & 6 & 112 & 52.0 & 0.84 & 5332 & 3.31 & 2.76 & 13.6 & \\
\hline 13 & 5 & 87 & 57.1 & 0.61 & 4673 & 3.39 & 2.83 & 13.1 & \\
\hline 14 & 4 & 82 & 43.7 & 0.92 & 6602 & 3.53 & 2.94 & 12.4 & \\
\hline 15 & 7 & 118 & 53.2 & 0.85 & 5440 & 3.55 & 2.96 & 12.3 & \\
\hline $16^{\mathrm{d}}$ & 3 & 66 & 54.7 & 0.99 & 5759 & 3.73 & 3.11 & 11.4 & \\
\hline $17^{\mathrm{a}}$ & 23 & 422 & 54.2 & - & 6233 & 4.19 & 3.50 & 9.6 & \\
\hline $18^{\mathrm{e}}$ & 4 & 90 & 33.7 & 1.54 & 8672 & 4.64 & 3.87 & 8.4 & $4 \mathrm{~d}$ \\
\hline 19 & 6 & 86 & 64.2 & 0.61 & 9871 & 7.69 & 6.41 & 4.4 & \\
\hline $20^{\mathrm{a}}$ & 6 & 68 & 48.0 & - & 12867 & 7.78 & 6.49 & 4.4 & \\
\hline $21^{\mathrm{d}}$ & 5 & 102 & 57.7 & 0.68 & 11893 & 8.47 & 7.06 & 4.0 & $3 a, 4 b$ \\
\hline $22^{\mathrm{a}}$ & 8 & 136 & 68.0 & - & 14945 & 12.48 & 10.41 & 2.6 & $4 a$ \\
\hline Average & & & 40.4 & 0.96 & 6618 & 3.55 & 2.96 & & \\
\hline
\end{tabular}

were estimated only for those whales tracked over $1 \mathrm{~h}$ (Table 3). Of the 22 tagged individuals examined, 14 had ingestion rates that were high enough to meet estimated daily metabolic requirements. However, 2 of these 14 would have needed to feed for nearly $24 \mathrm{~h}$ at the observed ingestion rates to meet this requirement, whereas 4 would have needed less than 5 h. The concentration of $C$. finmarchicus C5 explained $94 \%$ of the variation in the estimated ingestion rates when assessed with a regression model forced through the origin (Fig. 6). The resulting regression equation, i.e. $I^{\prime}=\left(6.58 \mathrm{~m}^{3} \mathrm{~W}\right) \times \mathrm{C}$, suggests that the minimum $C$. finmarchicus C5 concentration required to meet daily metabolic requirements is 3600 copepods $\mathrm{m}^{-3}$ (foraging would need to continue for $24 \mathrm{~h} \mathrm{~d}^{-1}$ to meet this requirement). The minimum peak concentration observed near whales that were tagged for over $1 \mathrm{~h}$ and that engaged in feeding dives was ca. 3000 copepods $\mathrm{m}^{-3}$ (Table 3), which is in good agreement with the minimum concentration required to meet daily metabolic requirements. One of the tagged whales engaged in behavior that we interpret as searching (Fig. 3d) and peak concentrations of $C$. finmarchicus C5 near this individual averaged ca. 1300 copepods $\mathrm{m}^{-3}$. A whale feeding continuously on this concentration (i.e. $24 \mathrm{~h}$ $\mathrm{d}^{-1}$ ) would ingest only $35 \%$ of its daily requirement on average, whereas feeding on a concentration of 3000 copepods $\mathrm{m}^{-3}$ would yield $83 \%$ of the daily requirement. The evidence from this single individual suggests that right whales may ignore $C$. finmarchicus C5 concentrations as low as 1300 copepods $\mathrm{m}^{-3}$ because foraging would not come close to meeting the daily requirement, yet peak concentrations over 3000 copepods $\mathrm{m}^{-3}$ that nearly provide the daily requirement may be more acceptable.

\section{DISCUSSION}

The stereotypical shape of feeding dives in North Atlantic right whales is optimized for exploiting zooplankton aggregated in discrete layers. Rapid descents and ascents reduce transit time to foraging depths, and these transit times are even further reduced when diving to deeper depths by increasing both descent and ascent rates. Thus, duration at the depth where feeding occurs is maximized. The significantly faster ascents relative to descents are due to the right whale's 


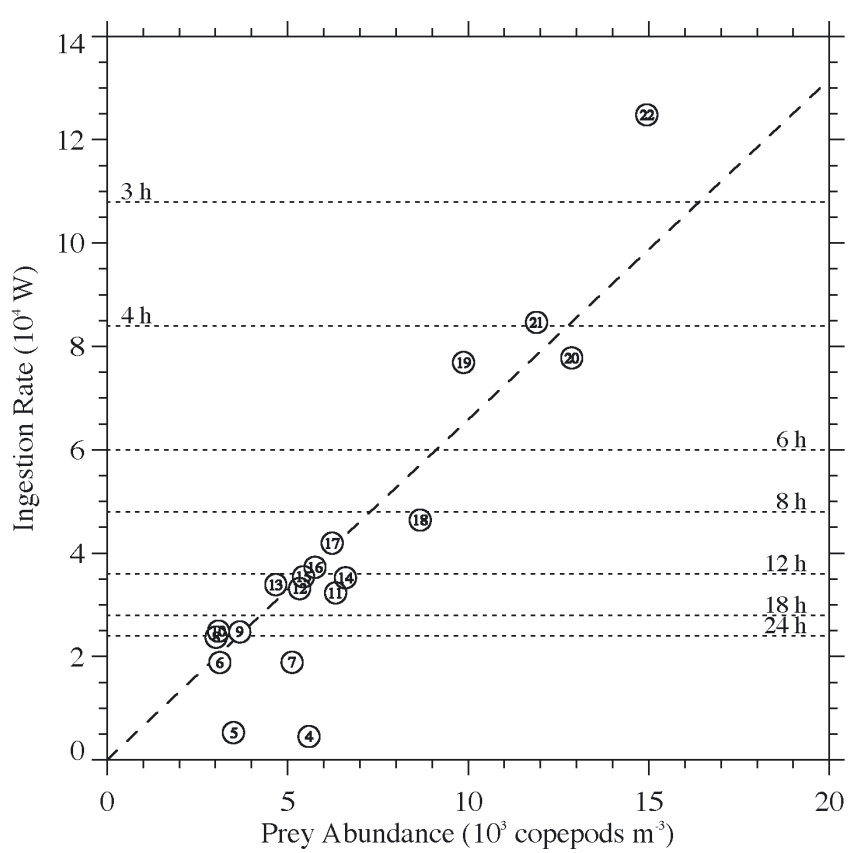

Fig. 6. Eubalaena glacialis and Calanus finmarchicus. Estimated ingestion rate versus average peak $C$. finmarchicus $\mathrm{C} 5$ abundance. (4) to (22): Labels for whales reference data in Table 3. A linear regression forced through the origin was fitted to the data and is shown as the dashed line. Horizontal, dotted lines indicate the ingestion rates and times spent foraging required to meet daily metabolic needs (e.g. ingestion for $8 \mathrm{~h} \mathrm{~d}^{-1}$ at a rate of $4.8 \times 10^{4} \mathrm{~W}$ would be sufficient to meet daily metabolic requirements)

positive buoyancy, which the whale must overcome by fluke stroking on descent, but is exploited to reduce energy expenditure by gliding on ascent (Nowacek et al. 2001). The low variability in dive depth during the at-depth portion of the feeding dive is in marked contrast to the high variability in dive depth exhibited by blue and fin whales (Croll et al. 2001). These differences are presumably related to feeding ecology. Right whales feed on zooplankton aggregated in discrete layers by continuously swimming with their mouths agape, but blue and fin whales are gulp feeders that engulf euphausiids or fish along with vast quantities of seawater in a single mouthful. The variability in dive depths during the at-depth portion of these rorquals' dives, therefore, has been interpreted as lunge feeding (Croll et al. 2001). The duration of the tagged right whales' dives (average $12.2 \mathrm{~min}$ ) were much longer than fin (5.5 min; Croll et al. 2001), blue (6.6 min; Croll et al. 2001) and humpback whales (2.8 min; Dolphin 1987). Croll et al. (2001) have suggested that increased dive durations in the Balaenidae (right and bowhead whales) are a result of lower metabolic costs associated with continuous filter feeding. Conversely, decreased dive durations in rorquals are a consequence of the higher metabolic costs associated with lunge feeding.
When dive durations exceed the capacity for aerobic metabolism, anaerobic metabolism causes lactate to build in the blood which must be cleared during the succeeding surfacing interval. Dives that exceed this aerobic dive limit (ADL), therefore, are associated with disproportionately longer surfacing intervals (Kooyman et al. 1980, 1983). Dolphin (1987) reported increasing PCST for humpback whale dives that exceeded $60 \mathrm{~m}$ in depth and suggested that this increased time at the surface was required to repay the oxygen debt incurred during anaerobic metabolism. In the present study, there was no evidence that PCST was correlated with either dive depth or duration for the tagged right whales. We observed average PCST values of $21.2 \%$ (excluding calves, females with calves and the pregnant female), which is in good agreement with PCST values for presumed aerobic dives by Weddell seals (21\%; Kooyman et al. 1980) and humpback whales (21.4\%; Dolphin 1987). These results suggest that the tagged right whales were diving within their ADL. Although the dive durations for calves and females with calves were similar to the other whales, surface intervals were significantly higher, which resulted in a higher PCST for calves and females with calves. The calves were seldom more than a body's length away from their presumed mothers and they often surfaced and dove simultaneously with the adult as well. The extended surface intervals and higher PCST values for the tagged females with calves, then, are interpreted as being governed by the calf's diving capabilities. Theoretical ADL is computed as the total oxygen stores divided by DMR and while total oxygen stores increase linearly with body mass $(M)$, DMR increases with $M^{0.75}$ (Costa \& Williams 1999). ADL is therefore proportional to $M^{0.25}$, so a calf's ADL will be lower than that of an adult simply due to its reduced body size. In addition to the effect of body size on ADL, calves must also have higher metabolic rates to fuel growth which will further reduce their ADL. Croll et al. (2001) estimated total $\mathrm{O}_{2}$ stores for blue and fin whales to be an average $55.6 \mathrm{ml} \mathrm{O}_{2} \mathrm{~kg}^{-1}$. Assuming right whales have similar total $\mathrm{O}_{2}$ stores and that a calf's DMR $=4 \times$ BMR (i.e. DMR $=4 \times\left[70 M^{0.75} \mathrm{kcal} \mathrm{d}^{-1}\right] /\left[4.8 \mathrm{kcal}\left(\mathrm{l} \mathrm{O}_{2}\right)^{-1}\right] /$ [1440 $\left.\mathrm{min} \mathrm{d}^{-1}\right]$ ), a $5000 \mathrm{~kg}$ calf (New England Aquarium unpubl. data cited in Brown et al. 2001) would have a theoretical ADL of $11.5 \mathrm{~min}$. Observed dive durations for calves and females with calves averaged $11.60 \min (\mathrm{n}=5, \mathrm{SD}=2.04 \mathrm{~min}$, range $=8.84$ to $14.09 \mathrm{~min})$. The prolonged surface intervals, elevated PCST values and these ADL calculations suggest that right whale calves may dive for durations close to their ADL, but caution is warranted when interpreting these results because of the low sample size and the uncertainty in estimating both total $\mathrm{O}_{2}$ stores and diving metabolic rate for right whales. 
The significantly longer surface intervals observed for calves, females with calves and the pregnant female may indicate that reproductively active females and their calves are at comparatively greater risk for collisions with ships than other animals in the population. Fujiwara \& Caswell (2001) estimated that the survivorship of right whale mothers declined from 1980 to 1995, while the survivorship of mature males and (noncalving) females remained unchanged over the same period. Higher rates of mortality among right whale mothers may be due to their use of the calving grounds off the southeast United States, where the volume of shipping traffic is high (Fujiwara \& Caswell 2001). However, our results suggest that the diving behavior of reproductively active females and their calves may also place them at greater risk of ship strikes on the feeding grounds as well.

The strong correlation between dive depths and the depth of maximum Calanus finmarchicus C5 abundance indicate that right whales are adept at locating and exploiting discrete layers of highly concentrated prey. The accuracy with which they target these layers would seem to rule out the possibility that right whales sample the water column mouthful by mouthful until they reach a suitable prey concentration. Instead, the transition from the descent phase to the at-depth portion of the dive occurs very quickly and the fidelity to the depth initially targeted is often remarkable. These observations suggest that right whales can detect layers of $C$. finmarchicus C5 without opening their mouths. The sensory mechanisms by which the whales accomplish this are unknown, but may include vision or sensory hairs (Kenney et al. 2001). Rowntree (1996) even suggests that the cyamid amphipods that inhabit right whale callosities may aid in locating prey. As is typical for turbid coastal environments, light levels at mid-depth in Grand Manan Basin are probably very low and vision would only be useful during daylight hours. C. finmarchicus do not bioluminesce as do some other copepods (e.g. Metridia spp.), so direct visual detection of prey in the absence of ambient light is probably not possible. Regardless of the sensory mechanisms employed, right whales may be able to restrict their search for suitable prey concentrations using cues from the physical environment. The tagged right whales rarely ventured into the bottom mixed layer proper and when they did so, it was typically during an excursion to the sea floor that seemed exploratory in nature. There are a variety of cues with which right whales can detect the presence of this mixed layer, including shear at the top of the layer (i.e. rapid velocity changes with depth), turbulence within the layer itself or particular temperature or salinity properties. With foraging experience, right whales may learn that suitable prey concentrations of $C$. finmarchicus are uncommon in the bottom mixed layer, so only occasional forays into this layer are necessary. Moreover, searching may be further restricted to only a few 10 s of $\mathrm{m}$ around the top of this boundary layer since C. finmarchicus C5 aggregate just above the bottom mixed layer at this time of year.

Our calculations suggest that many of the tagged right whales ingest Calanus finmarchicus $\mathrm{C} 5$ at rates sufficient to meet daily metabolic requirements. It is very important to bear in mind, however, that the selection of DMR $=2 \times$ $\mathrm{BMR}$, though based on sound reasoning, is truthfully only a guess. Metabolic rates have only been directly measured in species that can be captured and manipulated. Current methods of measuring metabolic rates cannot be applied to adult mysticetes. Croll et al. (2001) observed dive durations in blue and fin whales that were much shorter than calculated ADL values using DMR $=4 \times$ BMR. They inferred from these data that the metabolic costs of lunge feeding were well in excess of $4 \times$ BMR. The number of right whales deemed to be successfully foraging is quite sensitive to the choice of DMR (Fig. 7). If DMR values for right whales also exceed $4 \times \mathrm{BMR}_{\text {, then only }}$ 4 of the 22 individuals with tag attachments lasting over $1 \mathrm{~h}$ would have been ingesting $C$. finmarchicus $\mathrm{C} 5$ at a rate sufficient to meet their daily metabolic requirement (Fig. 7). Uncertainties in estimating metabolic rates inhibit our ability to accurately determine whether right whales are able to forage successfully. The development and application of new methods to directly measure either absolute or relative (i.e. diving vs. resting) metabolic rates for large cetaceans is sorely needed.

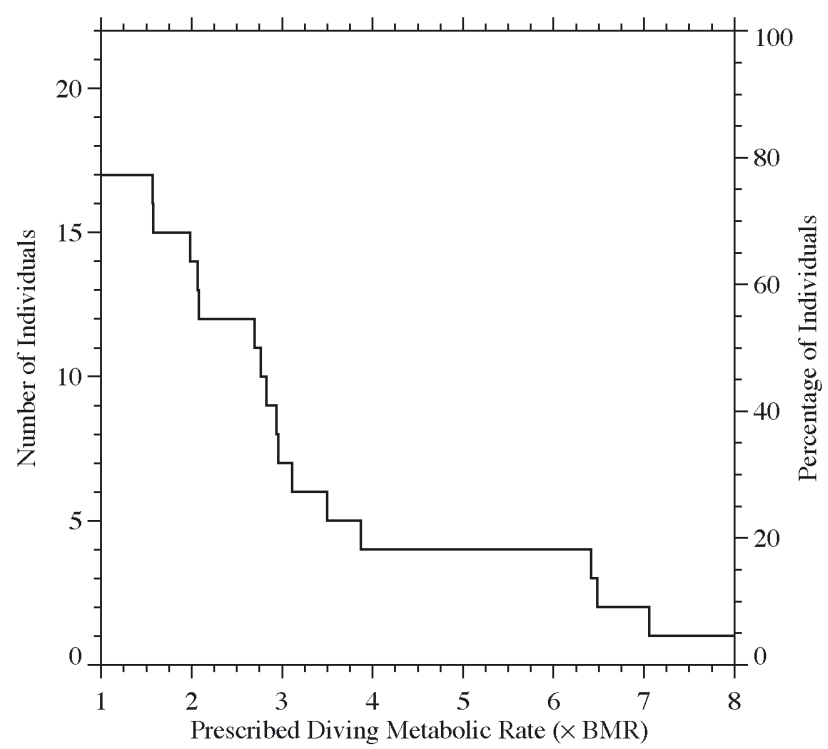

Fig. 7. Eubalaena glacialis. Number (and percentage) of whales shown in Table 3 that ingested prey at a rate sufficient to meet daily metabolic requirements for different choices of the diving metabolic rate (DMR). DMR shown as a multiple of the estimated basal metabolic rate (BMR) 
Despite the uncertainties in DMR, it is clear that some of the tagged whales were easily ingesting Calanus finmarchicus $\mathrm{C} 5$ at a rate sufficient to meet their daily metabolic requirements. These whales were able to identify and exploit very dense aggregations of C. finmarchicus C5, which indicates that food resources upon which individual right whales can survive seem to exist. Since no emaciated right whales were observed in the field and some tagged whales chose socializing with conspecifics over foraging, this result is in no way surprising. It seems clear that sufficient food resources exist for individual right whales to survive, but the benchmark for successful foraging in a viable population is not simply meeting daily or even annual maintenance requirements. Ingestion must also be sufficient to fuel reproduction, including the metabolic costs of social behavior (a rather energetic activity in right whales), growth of a fetus and support of a newborn calf via lactation. Of the 22 individuals examined, 15 ingested $C$. finmarchicus $\mathrm{C} 5$ at rates that would require more than half of the day to be dedicated to foraging just to meet daily metabolic requirements (Table 3). These results might suggest that sufficient food resources do not exist to support the elevated metabolic demands associated with reproduction for most of the population. However, a few caveats must be recalled before such a claim could be made.

The deployment durations during this study were short; most successful deployments were between 0.5 and $2 \mathrm{~h}$. Therefore, the ingestion rates estimated here may not accurately reflect daily ingestion rates. Since we observed a few whales foraging on abundances of Calanus finmarchicus C5 in excess of 10000 copepods $\mathrm{m}^{-3}$, we know that very dense concentrations are occasionally encountered. For those whales that had low ingestion rates during the period they were tagged, it is possible that they might also encounter similarly high abundances after several more hours of foraging effort. Accurate daily ingestion rates can only be obtained with deployments that last at least $24 \mathrm{~h}$. Ingestion rates can further be improved with direct swim speed measurements (relative to the water, not the ground), although we believe the error in the estimated ingestion rates attributable to a fixed swim speed $\left(1.5 \mathrm{~m} \mathrm{~s}^{-1}\right)$ is relatively small. In light of these considerations, we cannot judge whether sufficient food resources exist to support right whale population growth with our data. However, clear directions for future work are indicated. Day-long deployments with concurrent zooplankton sampling are necessary to obtain accurate daily ingestion rates. Day-long deployments would also yield data on the amount of time devoted to foraging ( $T$ in Eq. 3), resting and social activities. As mentioned before, innovative methods to measure metabolic rates in large cetaceans are also needed. Finally, it is important to obtain simi- lar measurements outside the lower Bay of Fundy throughout the spring-summer-fall feeding season. Since right whales are capable of storing fat, it is possible that feeding conditions elsewhere may provide the bulk of the energy required to meet reproductive metabolic costs (e.g. Beardsley et al. 1996). Focusing only on 1 feeding habitat, then, might provide a distorted view of whether sufficient food resources exist to support right whale population growth.

Acknowledgements. We are indebted to chief scientists T. Cole and P. Clapham, the master, officers and crew of NOAA Ship 'Delaware II' and the many professional and volunteer observers who made field operations possible. Particular thanks go to our able drivers, B. Lagerquist and F. Wenzel, and to P. Duley, T. Fernald and J. Nicolas for special assistance in the field. T. Follett contributed considerable expertise to the construction of the tags. Several people graciously loaned equipment for which we are grateful: M. Taylor provided the CTD, R. Trask provided the rosette cage, W. Pearcy provided the acoustic receiver and $H$. Dewar provided the directional hydrophone. R. Rolland conducted the fecal steroid hormone analysis to identify the pregnant female tagged in Roseway Basin. We are grateful to C. Miller, E. Durbin, R. Kenney and 2 anonymous reviewers for comments on earlier drafts of this manuscript. This research was supported by the National Marine Fisheries Service, Office of Naval Research and the Oregon State University Marine Mammal Endowment. M.F.B. was supported by the Space Grant and Earth System Science fellowship programs of the National Aeronautics and Space Administration.

\section{LITERATURE CITED}

Baumgartner MF (2003) Comparisons of Calanus finmarchicus fifth copepodite abundance estimates from nets and an optical plankton counter. J Plankton Res 25:855-868

Beardsley RC, Epstein AW, Chen C, Wishner KF, Macaulay MC, Kenney RD (1996) Spatial variability in zooplankton abundance near feeding right whales in the Great South Channel. Deep-Sea Res II 43:1601-1625

Brown MW, Brault S, Hamilton PK, Kenney RD and 5 others (2001) Sighting heterogeneity of right whales in the western North Atlantic: 1980-1992. J Cetacean Res Manage Spec Issue 2:245-250

Castellini MA, Kooyman GL, Ponganis, PJ (1992) Metabolic rates of freely diving Weddell seals: correlations with oxygen stores, swim velocity and diving duration. J Exp Biol 165:181-194

Caswell H, Fujiwara M, Brault S (1999) Declining survival probability threatens the North Atlantic right whale. Proc Natl Acad Sci USA 96:3308-3313

Clapham PJ, Young SB, Brownell Jr RL (1999) Baleen whales: conservation issues and the status of the most endangered populations. Mamm Rev 29:35-60

Comita GW, Marshall SM, Orr AP (1966) On the biology of Calanus finmarchicus. XIII. Seasonal change in weight, calorific value and organic matter. J Mar Biol Assoc UK 46:1-17

Conversi A, Piontkovski S, Hameed S (2001) Seasonal and interannual dynamics of Calanus finmarchicus in the Gulf of Maine (northeastern US shelf) with reference to the North Atlantic Oscillation. Deep-Sea Res II 48:519-530 Costa DP (1993) The secret life of marine mammals: novel 
tools for studying their behavior and biology at sea. Oceanography 6:120-128

Costa DP, Gentry RL (1986) Free-ranging energetics of northern fur seals, Callorhinus ursinus. In: Gentry RL, Kooyman GL (eds) Fur seals: maternal strategies on land and at sea. Princeton University Press, Princeton, NJ, p 79-101

Costa DP, Williams TM (1999) Marine mammal energetics. In: Reynolds JE III, Rommel SA (eds) Biology of Marine Mammals. Smithsonian Institution Press, Washington, District of Columbia, USA, p 176-217

Costa DP, Croxall JP, Duck C (1989) Foraging energetics of Antarctic fur seals, Arctocephalus gazella, in relation to changes in prey availability. Ecology 70:596-606

Croll DA, Acevedo-Gutiérrez A, Tershy BR, Urbán-Ramírez J (2001) The diving behavior of blue and fin whales: is dive duration shorter than expected based on oxygen stores? Comp Biochem Physiol A 129:797-809

Dolphin WF (1987) Dive behavior and estimated energy expenditure of foraging humpback whales in southeast Alaska. Can J Zool 65:354-362

Fromentin J, Planque B (1996) Calanus and environment in the eastern North Atlantic. II. Influence of the North Atlantic Oscillation on C. finmarchicus and C. helgolandicus. Mar Ecol Prog Ser 134:111-118

Fujiwara M, Caswell H (2001) Demography of the endangered North Atlantic right whale. Nature 414:537-541

Greene CH, Pershing AJ (2000) The response of Calanus finmarchicus populations to climate variability in the Northwest Atlantic: basin-scale forcing associated with the North Atlantic Oscillation. ICES J Mar Sci 57:1536-1544

Goodyear JD (1993) A sonic/radio tag for monitoring dive depths and underwater movements of whales. J Wildl Manage 57:503-513

Hamilton PK, Martin SM (1999) A catalog of identified right whales from the western North Atlantic: 1935 - 1997. New England Aquarium, Boston, MA

Herman AW (1988) Simultaneous measurement of zooplankton and light attenuance with a new optical plankton counter. Cont Shelf Res 8:205-221

Herman AW (1992) Design and calibration of a new optical plankton counter capable of sizing small zooplankton. Deep-Sea Res 39:395-415

International Whaling Commission (IWC) (2001) Report of the workshop on status and trends of western North Atlantic right whales. J Cetacean Res Manage Spec Issue 2:61-87

Johnson DE (1998) Applied multivariate methods for data analysts. Duxbury Press, Pacific Grove, CA

Kenney RD, Winn HE (1986) Cetacean high-use habitats of the northeast United States continental shelf. Fish Bull 84:345-357

Kenney RD, Hyman MAM, Owen RE, Scott GP, Winn HE (1986) Estimation of prey densities required by western North Atlantic right whales. Mar Mamm Sci 2:1-13

Kenney RD, Winn HE, Macaulay MC (1995) Cetaceans in the Great South Channel, 1979 - 1989: right whale (Eubalaena glacialis). Cont Shelf Res 15:385-414

Kenney RD, Mayo CA, Winn HE (2001) Migration and foraging strategies at varying spatial scales in western North Atlantic right whales: a review of hypotheses. J Cetacean Res Manage Spec Issue 2:251-260

Kleiber M (1975) The Fire of Life: an introduction to animal energetics. RE Kreiger Publishing Co, Huntington, NY

Knowlton AR, Kraus SD, Kenney RD (1994) Reproduction in North Atlantic right whales (Eubalaena glacialis). Can J Zool 72:1297-1305

Kooyman GL (1989) Diverse divers: physiology and behavior. Springer-Verlag, Berlin
Kooyman GL, Kerem DH, Campbell WB, Wright JJ (1973) Pulmonary gas exchange in freely diving Weddell seals. Respir Physiol 17:283-290

Kooyman GL, Wahrenbrock EA, Castellini MA, Davis RW, Sinnett EE (1980) Aerobic and anaerobic metabolism during voluntary diving in Weddell seals: evidence of preferred pathways from blood chemistry and behavior. J Comp Physiol B 138:335-346

Kooyman GL, Castellini MA, Davis RW, Maue RA (1983) Aerobic diving limits of immature Weddell seals. J Comp Physiol B 151:171-174

Kraus SD, Hamilton PK, Kenney RD, Knowlton AR, Slay CK (2001) Reproductive parameters of the North Atlantic right whale. J Cetacean Res Manage Spec Issue 2: $231-326$

Lockyer C (1981) Growth and energy budgets of large baleen whales from the Southern Hemisphere. In: FAO Advisory Committee on Marine Resource Research, Mammals in the sea, Vol III. General papers and large cetaceans. FAO, Rome, p 379-487

Mayo CA, Marx MK (1990) Surface foraging behavior of the North Atlantic right whale, Eubalaena glacialis, and associated zooplankton characteristics. Can J Zool 68: $2214-2220$

Mayo CA, Letcher BH, Scott S (2001) Zooplankton filtering efficiency of the baleen of a North Atlantic right whale, Eubalaena glacialis. J Cetacean Res Manage Spec Issue 2: 225-229

Miller CB, Cowles TJ, Wiebe PH, Copley NJ, Grigg H (1991) Phenology in Calanus finmarchicus; hypotheses about control mechanisms. Mar Ecol Prog Ser 72:79-91

Murison LD, Gaskin GE (1989) The distribution of right whales and zooplankton in the Bay of Fundy, Canada. Can J Zool 67:1411-1420

Nowacek DP, Johnson MP, Tyack PL, Shorter KA, McLellan WA, Pabst DA (2001) Buoyant balaenids: the ups and downs of buoyancy in right whales. Proc R Soc Lond B 268: 1811-1816

Payne PM, Wiley DN, Young SB, Pittman S, Clapham PJ, Jossi JW (1990) Recent fluctuations in the abundance of baleen whales in the southern Gulf of Maine in relation to changes in selected prey. Fish Bull 88:687-696

Rowntree VJ (1996) Feeding, distribution, and reproductive behavior of cyamids (Crustacea: Amphipoda) living on humpback and right whales. Can J Zool 74:103-109

Sameoto DD, Herman AW (1990) Life cycle and distribution of Calanus finmarchicus in deep basins on the Nova Scotia shelf and seasonal changes in Calanus spp. Mar Ecol Prog Ser 66:225-237

Stone GS, Kraus SD, Prescott JH, Hazard KW (1988) Significant aggregations of the endangered right whale, Eubalaena glacialis, on the continental shelf of Nova Scotia. Can Field-Nat 102:471-474

Watkins WA, Schevill WE (1976) Right whale feeding and baleen rattle. J Mammal 57:58-66

Wishner K, Durbin E, Durbin A, Macaulay M, Winn $H$, Kenney R (1988) Copepod patches and right whales in the Great South Channel off New England. Bull Mar Sci 43: 825-844

Wishner KF, Schoenherr JR, Beardsley R, Chen C (1995) Abundance, distribution and population structure of the copepod Calanus finmarchicus in a springtime right whale feeding area in the southwestern Gulf of Maine. Cont Shelf Res 15:475-507

Woodley TH, Gaskin DE (1996) Environmental characteristics of North Atlantic right and fin whale habitat in the lower Bay of Fundy, Canada. Can J Zool 74:75-84

Submitted: February 27, 2003; Accepted: September 15, 2003 Proofs received from author(s): December 2, 2003 